\title{
ANALISIS SAHAM BERDASARKAN CAPM PADA JAKARTA ISLAMIC INDEKS (JII) PERIODE 2014-2019
}

\author{
Esi Fitriani Komara \\ Program Studi Manajemen Fakultas Ekonomi dan Bisnis Universitas Jenderal Achmad Yani \\ esi.fk@lecture.unjani.ac.id \\ Eka Yulianti \\ Program Studi Manajemen Fakultas Ekonomi dan Bisnis Universitas Jenderal Achmad Yani \\ eka.yulianti@lecture.unjani.ac.id
}

\begin{abstract}
Abstrak: Analisis Saham Berdasarkan CAPM Pada Jakarta Islamic Indeks (JII) Periode 20142019 Investor dalam memilih sekuritas atau surat berharga yang akan diinvestasikan dapat menggunakan pendekatan Capital Asset Pricing Model (CAPM). Tujuan penelitian ini untuk menganalisis saham-saham JII yang layak untuk diinvestasikan berdasarkan CAPM periode 2014-2019. Teknik analisis data yang digunakan dalam penelitian ini adalah uji regresi sederhana, uji asumsi klasik dan uji stasioneritas data. Hasil Penelitian ini bahwa pada periode Januari 2014 sampai Desember 2019 menghasilkan 7 dari 12 sampel memiliki nilai $\beta>1$, yaitu saham ADRO, ASII, BSDE, INDF, KLBF, SMGR, dan WIKA. Kemudian, 9 saham dari 12 sampel yang menghasilkan nilai excess return positif (undervalue), yaitu ADRO, ASII, BSDE, ICBP, INDF, KLBF, TLKM, UNVR, dan WIKA. Selanjutnya nilai signifikansi kedua belas saham tersebut $<0,05$. Artinya ada hubungan antara risiko dan return saham kedua belas saham tersebut. Kriteria-kriteria yang digunakan untuk menilai saham dengan menggunakan model penelitian Yohantin (2009), Sehingga dapat disimpulkan bahwa dalam penelitian ini terdapat enam saham yang layak untuk diinvestasikan, yaitu ADRO, ASII, BSDE, INDF, KLBF, dan WIKA.
\end{abstract}

Kata kunci: Analisis Saham, Capital Asset Pricing Model

Abstract: Stock Analysis Based on CAPM in the Jakarta Islamic Index (JII) for the 20142019 period. Investors in choosing securities or securities to be invested can use the Capital Asset Pricing Model (CAPM) approach. The purpose of this study is to analyze the JII shares that are eligible to be invested based on the 2014-2019 CAPM. Data analysis techniques used in this study are simple regression tests, classic assumption tests and data stationarity tests. The results of this study that in the period January 2014 to December 2019 produced 7 of the 12 samples having a value of $\beta>1$, namely ADRO, ASII, BSDE, INDF, KLBF, SMGR, dan WIKA. Then, 9 stocks from 12 samples that produce positive excess return value (undervalued), namely ADRO, ASII, BSDE, ICBP, INDF, KLBF, TLKM, UNVR, dan WIKA. Furthermore, the significance value of the twelve shares is $<0.05$. This means that there is a relationship between risk and stock returns to the twelve shares. The criteria are used to assess stocks using the research model Yohantin (2009), so it can be concluded that in this study there are six stocks that are worth investing in, namely ADRO, ASII, BSDE, INDF, KLBF, dan WIKA.

Keywords: Stock Analysis, Capital Asset Pricing Model

PENDAHULUAN

Keputusan dalam berinvestasi merupakan salah satu hal yang paling penting bagi investor, hal tersebut dikarenakan keputusan investasi berkaitan dengan keuntungan (return) dan resiko dari investasi 


\section{Nominal: Barometer Riset Akuntansi dan Manajemen}

P-ISSN: 2303-2065 E-ISSN: 2502-5430

Volume 10 No 1 (2021)

yang akan dilakukan. Investor selalu berharap untuk mendapatkan tingkat keuntungan yang maksimal dengan risiko yang minimal dari investasi yang dilakukan. Salah satu dari sekian banyak alternatif investasi yang bisa pilih oleh investor dalam berinvestasi yaitu investasi di pasar modal, misalnya investasi pada sekuritas ataupun surat berharga lainnya. Investasi pada saham atau sekuritas akan dihadapkan pada return dan risiko. Dimana jika return tinggi maka risiko yang akan dihadapi akan tinggi juga. Sehingga, dalam memilih sekuritas, investor perlu berhati-hati. Salah satu strategi yang sering dilakukan oleh investor agar dapat meminimalkan risiko adalah dengan melakukan diversifikasi (pengkombinasian) yaitu berinvestasi pada beberapa saham dengan tujuan untuk mendapatkan return yang dapat menutupi kerugian dari saham yang lain. Sehingga dapat meningkatkan keuntungan dengan risiko tertentu atau mengurangi risiko dengan return tertentu.

Memprediksi saham mana yang akan dipilih merupakan salah satu hambatan yang di alami investor dalam pengambilan keputusan investasi pada saham. Hal tersebut karena akan berpengaruh terhadap seberapa besar tingkat keuntungan yang akan diperoleh dengan risiko yang akan dihadapi.

Menurut (Yohantin, 2009) Capital Asset Pricing Model (CAPM) merupakan salah satu model dapat digunakan investor dalam memilih saham yang layak untuk diinvestasikan. Model ini diperkenalkan oleh (Sharpe, 1964), dan (Lintner, 1965) yang merupakan model keseimbangan yang dapat menghubungan tingkat keuntungan dengan risiko. Sehingga model ini dapat memprediksi tingkat keuntungan suatu sekuritas. Tingkat keuntungan dan risiko berkorelasi positif dan linier. Variabel $\beta$ (beta) merupakan ukuran risiko dalam CAPM. Jika $\beta$ suatu saham tinggi, menunjukan bahwa saham tersebut memiliki risiko yang tinggi pula (Yohantin, 2009). Selain itu, dalam CAPM, pasar modal adalah efisien artinya investor dapat melakukan jual beli saham setiap saat (Hidayati, Suhadak and Nengah, 2014).

Bursa Efek Indonesia (BEI) merupakan pasar modal Indonesia yang melakukan kegiatan jual beli sekuritas. Dalam artian bahwa BEI merupakan tempat untuk memperjualbelikan sekuritas. Sehingga investor dapat memperjualbelikan sekuritas yang dimilikinya. Di Bursa Efek Indonesia terdiri dari perusahaan-perusahaan yang sudah termasuk kedalam perusahaan terbuka. Salah satu kelompok saham yang menarik perhatian investor dalam berinvestasi saham adalah Jakarta Islamic Indeks (JII) karena sekuritas-sekuritas yang termasuk kedalam indeks ini memiliki tingkat likuiditas tinggi dan kapitalisasi besar. Perkembangan kapitalisasi pasar Jakarta Islamic Indeks (JII) periode 2014 - 2019 disajikan pada gambar 1. 


\section{Nominal: Barometer Riset Akuntansi dan Manajemen}

P-ISSN: 2303-2065 E-ISSN: 2502-5430

Volume 10 No 1 (2021)

Berdasarkan gambar 1, bahwa kapitalisasi pasar Jakarta Islamic Indeks (JII) secara umum mengalami kenaikan, walaupun pada tahun 2015 dan 2018 sempat mengalami penurunan.

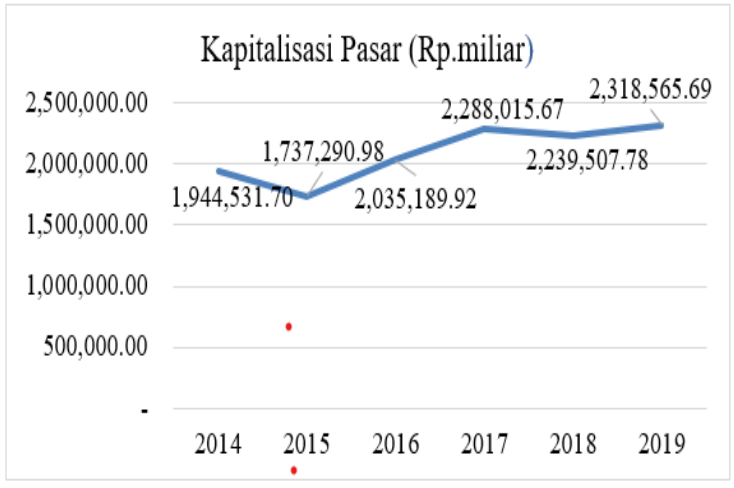

Gambar 1. Perkembangan Kapitalisasi Pasar

JII Periode 2014-2019

Selain itu, Capital Asset Pricing Model (CAPM) valid di Jakarta Islamic Indeks (JII).

Hal tersebut sesuai dengan hasil penelitian (Komara, Febrian and Anwar, 2019). Sehingga CAPM bisa digunakan sebagai model yang dapat memprediksi saham-saham apa saja yang layak diinvestasikan di Jakarta Islamic Indeks (JII).

Penelitian tentang Capital Asset Pricing Model (CAPM) dalam mengestimasi nilai kelayakan investasi saham dilakukan oleh (Yohantin, 2009), hasil penelitiannya disimpulkan bahwa dari 9 saham yang dijadikan sampel hanya 5 saham JII periode 2004-2008 yang memenuhi kriteria sebagai saham yang dapat dipilih untuk diinvestasikan. Adapun kriteria yang dimaksud yaitu saham tersebut merupakan saham yang memiliki beta $(\beta)$ lebih dari 1 dalam artian saham tersebut terkategori agresif, kemudian menghasilkan excess return yang positif, selain itu, risiko dan return saham memiliki hubungan linier dan menghasilkan $\beta$ yang signifikan.

Penelitian yang dilakukan oleh (Hardiyanti, Prijanto And Amsori, 2020) yang melakukan penelitian tentang penilaian return dan risiko dengan menggunakan CAPM pada JII periode 2014-2016, bahwa terdapat 12 saham yang layak untuk diinvestasikan yaitu ADRO, AKRA, ASII, BSDE, INDF, KLBF, LSIP, SMRA, TLKM, UNTR, UNVR dan WIKA.

Kemudian penelitian yang dilakukan oleh (Anton and Ervita Safitri, 2014) yang menganalisis hubungan return dan risiko saham dengan menggunakan CAPM Pada JII periode 2009-2012. Hasil penelitiannya menyimpulkan bahwa terdapat 4 saham yang bisa dijadikan referensi investor dalam berinvestasi, yaitu KLBF, LSIP, TLKM, dan UNVR.

Selanjutnya, Penelitian (Ramli, 2010). Hasilnya menyatakan bahwa dari 15 sampel hanya 5 saham yang layak diinvestasikan. Adapun kriteria yang digunakan adalah saham tersebut tergolong undervalue yaitu nilai expected return lebih besar dari return actual.

Selain itu, penelitian (Nasuha, Dzulkirom and A, 2012), menyatakan bahwa dari 19 


\section{Nominal: Barometer Riset Akuntansi dan Manajemen}

P-ISSN: 2303-2065 E-ISSN: 2502-5430

Volume 10 No 1 (2021)

saham hanya 14 saham real estate yang layak untuk diinvestasikan karena tergolong kedalam saham yang undervalued. Penelitian (Putra and Irmadariani, 2014), hasil penelitiannya menyatakan bahwa dari 22 sampel hanya 5 saham indeks LQ-45 periode 2009-2013 yang layak untuk diinvestasikan. Dengan kriteria bahwa nilai (beta) $\beta$ lebih dari 1, menghasilkan excess return yag positif, serta risiko sistematis memiliki pengaruh positif signifikan terhadap expected return.

Serta, (Hidayati, Suhadak and Nengah, 2014), hasil penelitiannya menyatakan bahwa dari 18 sampel, ada 8 saham yang efisien, dan (Saputra, Suhadak and Azizah, 2015), penelitiannya menyimpulkan bahwa dari 37 sampel, yang termasuk pada saham yang efisien ada 16 saham. Kemudian, penelitian (Sekarwati and Margasari, 2015), hasilnya bahwa dari 51 sampel, terdapat 25 saham yang termasuk saham yang efisien karena $\mathrm{Ri}$ $>\mathrm{E}(\mathrm{Ri})$ dan terdapat hubungan yang linier natara risiko sistematis dan return yang diharapkan.

Berdasarkan uraian diatas, maka penelitian ini bertujuan untuk menganalisis saham-saham JII yang layak untuk diinvestasikan berdasarkan CAPM periode 2014-2019.

\section{KAJIAN LITERATUR}

\section{Return dan Risiko}

Return merupakan faktor yang memotivasi investor dalam berinvestasi.
Selain itu return merupakan pengembalian pendapatan atau hasil yang diperoleh investor dari investasi pilih (Komara, Febrian and Anwar, 2019). Sedangkan risiko merupakan faktor yang pasti dihadapi oleh investor dalam melakukan suatu investasi. Berdasarkan hasil penelitian yang dilakukan oleh (Black, Jensen, Michael and Scholes, 1972), bahwa return dan risiko/beta memiliki hubungan yang linier. Selain itu, (Brav, Lehavy and Michaely, 2005) menyatakan bahwa return ekspektasi dan beta pasar memiliki hubungan yang kuat. Artinya risiko yang dihadapi suatu asset tinggi maka return yang akan diperoleh dari aset tersebut akan tinggi juga.

\section{Capital Asset Pricing Theory (CAPM)}

(Sharpe, 1964), dan (Lintner, 1965) merupakan para ahli yang pertama kali mengembangkan CAPM. Model ini menjelaskan bahwa dalam kondisi ekuilibrium, return asset merupakan jumlah dari risk free rate ditambah beta kemudian dikali excess return. Sehingga model CAPM dinyatakan dengan rumus (Lintner, 1965), dan (Sharpe, 1964):

$\left.E\left(R_{i}\right)=R_{F}+\beta_{i}\left[(E R M)-R_{F}\right)\right]$

Dimana:

$\mathrm{E}(\mathrm{Ri})=$ Ekspektasi return saham

$\mathrm{Rf}=$ Return aset bebas risiko

$\mathrm{Rm} \quad=$ Return portofolio pasar

$\beta \mathrm{i} \quad=$ Risiko sistematis dari saham $\mathrm{i}$

Studi Pendahuluan Mengenai Analisis Saham Berdasarkan CAPM 
Banyak Penelitiaan berkaitan dengan analisis saham berdasarkan CAPM. Akan tetapi menujukan hasil yang berbeda-beda.

Penelitian yang dilakukan oleh (Hardiyanti, Prijanto and Amsori, 2020) yang melakukan penelitian tentang penilaian return dan risiko dengan menggunakan CAPM pada JII periode 2014-2016, bahwa terdapat 12 saham yang layak untuk diinvestasikan yaitu ADRO, AKRA, ASII, BSDE, INDF, KLBF, LSIP, SMRA, TLKM, UNTR, UNVR dan WIKA.

Penelitian yang dilakukan oleh (Anton and Ervita Safitri, 2014) yang menganalisis hubungan return dan risiko saham dengan menggunakan CAPM Pada JII periode 20092012. Hasil penelitiannya menyimpulkan bahwa terdapat 4 saham yang bisa dijadikan referensi investor dalam berinvestasi, yaitu KLBF, LSIP, TLKM, dan UNVR.

Penelitian yang dilakukan oleh (Sekarwati and Margasari, 2015), menyatakan bahwa Dari 100 sampel, 25 saham yang termasuk saham yang efisien karena $\mathrm{Ri}$ lebih besar dari $\mathrm{E}(\mathrm{Ri})$ dan risiko dan return memiliki hubungan yang linier. (Putra, M, D and Yadnya, I, 2016), menyatakan bahwa saham yang termasuk undervalued sebanyak 15 saham, sehingga ke 15 saham tersebut sebaiknya dibeli.

(Haidiati, Topowijono and Azizah, D, 2016), menyatakan bahwa terdapat 9 saham yang termasuk kedalam saham efisien.
Kemudian penelitian (Yulianti, Topowijono and Azizah, D, 2016), saham yang termasuk kedalam saham efisien sebanyak 6 saham.

Sedangkan menurut penelitian, (Kurniawan, F, Raden, R and Devi, F, 2015) saham yang masuk kedalam saham yang efisien sebanyak 14 saham. Sehingga sebaiknya investor membeli saham tersebut karena saham-saham tersebut termasuk kedalam saham yang undervalued. Akan tetapi, penelitian (Saputra, Suhadak and Azizah, 2015), menyatakan bahwa dari 37 sampel, hanya 21 saham yang termasuk kedalam kelompok efisien.

Selanjutnya, penelitian (Putra, M, D and Yadnya, I, 2016), hasil penelitiannya menyatakan bahwa dari 22 sampel hanya 8 saham yang layak untuk berinvestasi karena beta lebih dari 1, memiliki nilai excess return positif, dan risiko sistematis berpengaruh positif signifikan terhadap expected return.

(Hidayati, Suhadak and Nengah, 2014), menyatakan bahwa dari 18 sampel, ada 8 saham yang efisien karena $\mathrm{Ri}>\mathrm{E}(\mathrm{Ri})$. (Nasuha, Dzulkirom and A, 2012), menyatakan bahwa dari 19 sampel, ada 14 saham yang undervalue. Sedangkan (Yohantin, 2009), menyatakan bahwa terdapat 5 saham yang layak untuk diinvestasikan, karena memenuhi kriteria $\beta$ lebih dari 1, memiliki nilai excess return positif, adanya korelasi yang linier antara risiko dan return serta nilai $\beta$ saham 
signifikan. Sedangkan, penelitian yang dilakukan oleh (Ramli, 2010), hasil penelitiannya menyatakan bahwa dari 15 sampel, ada 5 emiten yang layak diinvestasikan karena undervalue.

\section{METODE PENELITIAN}

\section{Design Penelitian}

Penelitian ini menggunakan metode pendekatan kuantitatif deskriptif dan asosiatif. Metode deskriptif digunakan untuk mendeskripsikan sampel penelitian yang bertujuan untuk mempermudah menginterpretasikan data. Sedangkan metode asosiatif yang digunakan adalah penelitian kausalitas yang bertujuan untuk mengetahui pengaruh antara variabel $\mathrm{X}(\mathrm{Rm}-\mathrm{Rf})$ terhadap variabel Y (Ri-Rf).

\section{Tempat dan Waktu Penelitian}

Penelitian ini dilakukan dengan pengambil data sekunder perusahaan yang terdaftar di Bursa Efek Indonesia. Data yang digunakan diperoleh dari website resmi Bursa Efek Indonesia (www.idx.co.id), yahoo finance (www.finance.yahoo.com), dunia investasi (www.duniainvestasi.com) dan Bank Indonesia (www.bi.go.id). Pengumpulan dan pengolahan data dilaksanakan bulan november 2020 .

\section{Subjek Penelitian}

Penelitian ini menggunakan semua saham yang termasuk kedalam JII periode
2014-2019 sebanyak 50 emiten sebagai populasi. Teknik sampel yang digunakan dalam penelitian ini adalah purposive sampling. Berdasarkan kriteria dalam pengambilan sampel diperoleh sampel sebanyak 12 emiten.

\section{Operasionalisasi Variabel}

Variabel penelitian ini yaitu return saham individu ( $\mathrm{Ri})$, expected stock return $(\mathrm{E}(\mathrm{Ri}))$, return pasar $(\mathrm{Rm})$, expected market return $(\mathrm{E}(\mathrm{Rm}))$, indeks pasar, risk free rate $(\mathrm{RF})$, systematic risk $(\beta)$, dan required return $(\mathrm{E}(\mathrm{Rj}))$. Operasionalisasi Variabel disajikan pada tabel 1.

Tabel 1. Operasionalisasi Variabel

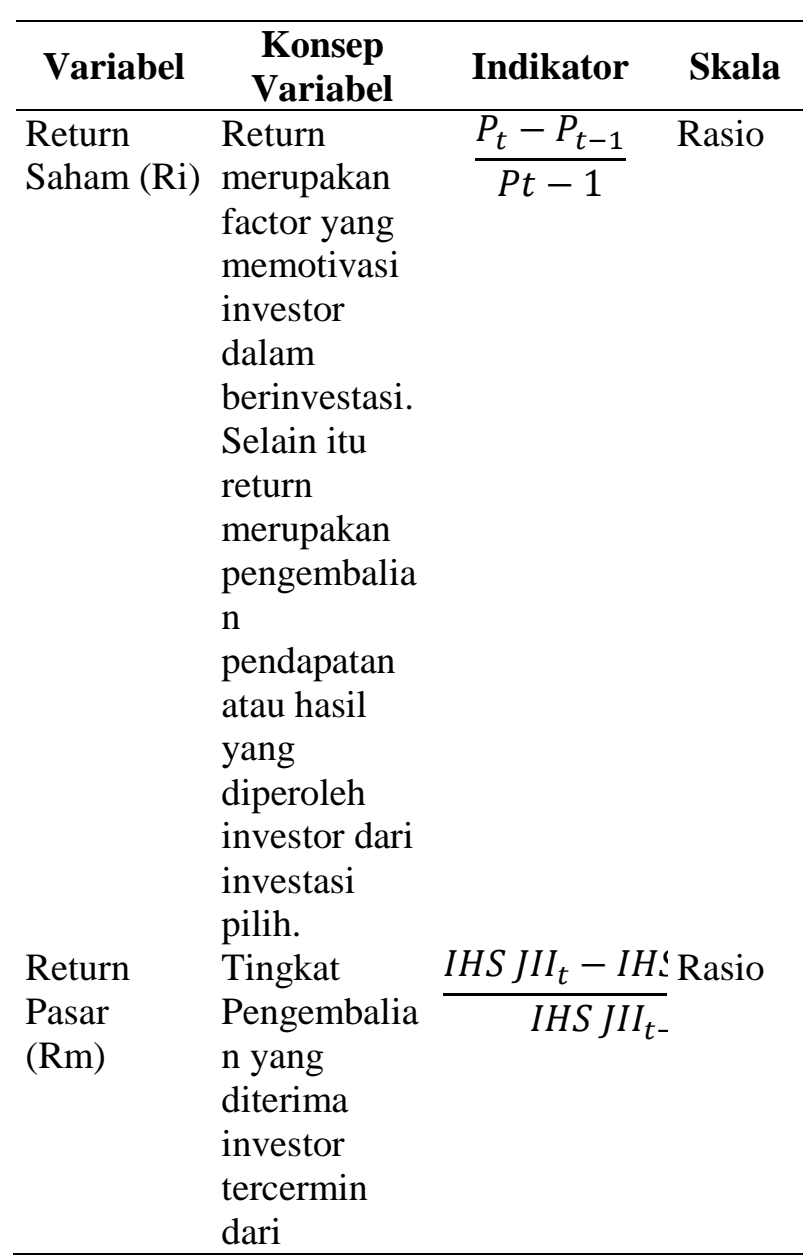




\begin{tabular}{|c|c|c|c|}
\hline Variabel & $\begin{array}{c}\text { Konsep } \\
\text { Variabel }\end{array}$ & Indikator & Skala \\
\hline & $\begin{array}{l}\text { perubahan } \\
\text { indeks harga } \\
\text { periode } \\
\text { tertentu }\end{array}$ & & \\
\hline
\end{tabular}

\section{Analisis Data}

Penelitian ini menggunakan analisis data kuantitatif menggunakan alat statistik yaitu program Eviews versi 8. Tahapan Analisis kuantitatif yang dimaksud adalah sebagaimana yang akan dibahas pada bagian berikut ini :

1. Mengumpulkan data closing price saham JII pada akhir bulan selama periode 20142019

2. Menghitung tingkat keuntungan masingmaisng saham (Ri) bulanan selama periode 2014-2019 dengan rumus sebagai berikut:

$$
\mathrm{Ri}=\frac{\underline{\mathrm{P}}_{\mathrm{t}}-\mathrm{P}_{\mathrm{t}-1}}{\mathrm{P}_{\mathrm{t}-1}}
$$

Dimana:

$\mathrm{Ri}=$ Return saham

$\mathrm{Pt}=$ Harga saham pada periode $\mathrm{t}$

$\mathrm{Pt}_{-1}=$ Harga saham pada periode $\mathrm{t}-1$

3. Menghitung Expected stock return (E(Ri)) selama periode 2014-2019 dengan rumus sebagai berikut:

$\mathrm{E}(\mathrm{Ri})=\frac{\sum \mathrm{Ri}}{n}$

Dimana:

$$
\begin{array}{ll}
\mathrm{E}(\mathrm{Ri}) & =\text { Expected stock return } \\
\sum \mathrm{Ri} & =\text { jumlah keuntungan saham } \\
\mathrm{n} & =\text { Jumlah data }
\end{array}
$$

4. Menghitung tingkat pengembalian pasar (Rm) bulanan selama periode 2014-2019 dengan rumus sebagai berikut:

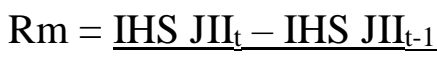
IHS JII ${ }_{t-1}$

Keterangan:

$\mathrm{Rm}=$ Return pasar

IHS JIIt = Indeks harga saham JII pada periode $\mathrm{t}$

IHS JIIt-1 = Indeks harga saham JII pada periode $\mathrm{t}-1$

5. Menghitung Expected market return $(\mathrm{E}(\mathrm{Rm}))$ selama periode 2014-2019 dengan rumus sebagai berikut:

$\mathrm{E}(\mathrm{Rm})=\frac{\sum \mathrm{Rm}}{n}$

Dimana:

$\mathrm{E}(\mathrm{Rm})=$ Expected market return

$\sum \mathrm{Rm}=$ jumlah keuntungan pasar

$\mathrm{n}=$ Jumlah data

6. Menghitung Risk Free rate (Rf) dengan menggunakan proxy suku bunga Sertifikat Bank Indonesia (SBI) bulanan selama periode 2014-2019 dengan rumus sebagai berikut:

\section{$\underline{\mathrm{SBI}_{t}}$}

12

7. Menghitung Ri-Rf dan Rm-Rf selama periode 2014-2019

8. Menghitung risiko sistematis atau beta $(\beta)$ saham

CAPM menyatakan bahwa nilai beta $\left(\beta_{\mathrm{i}}\right)$ besar maka return yang akan diperoleh akan semakin besar pula. Jika Beta saham 
lebih dari $1(\beta>1)$ menunjukan bahwa saham tersebut memiliki risiko tinggi. Sedangkan sebaliknya jika beta saham kurang dari $1(\beta<1)$ menunjukan bahwa saham tersebut memiliki risiko rendah (Putra, M, D and Yadnya, I, 2016).

Beta saham diperoleh dengan melakukan regresi linier sederhana, dimana variabel independen yaitu $\mathrm{Rm}-\mathrm{Rf}$ sedangkan variabel dependen yaitu Ri-Rf. Berikut ini adalah persamaan regresi sederhana dalam CAPM :

$\mathrm{Ri}=\mathrm{Rf}+(\mathrm{Rm}-\mathrm{Rf}) \beta$

Dimana:

$\mathrm{Ri}=$ Tingkat pengembalian saham

$\mathrm{Rm}=$ Tingkat pengembalian pasar

$\mathrm{Rf}=$ Tingkat pengembalian bebas risiko

$\beta=$ Tingkat risiko sistematis masingmasing saham

9. Required return $\left(\mathrm{E}\left(\mathrm{R}_{\mathrm{J}}\right)\right)$ bulanan selama periode 2014-2019 dengan rumus sebagai berikut:

$$
E(R i)=R_{F}+\beta_{i}\left[E\left(R_{M}\right)-R_{F}\right]
$$

Dimana:

$\mathrm{E}(\mathrm{Rj}) \quad=$ Required return

$\mathrm{E}(\mathrm{Rm}) \quad=$ Tingkat pengembalian yang diharapkan pasar

Rf $\quad=$ Tingkat pengembalian bebas risiko

$\beta \quad=$ Tingkat risiko sistematis masing - masing saham

10. Klasifikasi saham sebagai keputusan investasi
Saham yang terpilih harus memenuhi kriteria sebagai berikut (Ross, A, Westerfield, R and Jordan, B, 2010) :

a. Beta saham lebih dari 1 , artinya saham terebut tergolong saham yang agresif.

b. Menghasilkan Excess return yang positif $(+)$ atau $E(R i)>E(R j)$

c. Risiko dan return saham memiliki hubungan yang linier

d. Menghasilkan beta $(\beta)$ yang signifikan

11. Uji Asumsi Klasik yang terdiri dari uji normalias, autokorelasi, multikolinieritas dan heteroskedastisitas

12. Uji Stasioneritas data

Penelitian ini menggunakan cara uji akar unit (uji unit root) atau sering disebur dengan uji formal. Uji ini disebut juga sebagai Dickey-Fuller (DF) test, yang di kembangkan oleh David Dickey dan Wayne Fuller.

\section{HASIL PENELITIAN DAN}

\section{PEMBAHASAN}

\section{Klasifikasi Saham Sebagai Keputusan Investasi}

Berdasarkan metode diatas, dimana proses pengolahan data tersebut dikerjakan dengan bantuan program Eviews 8. Kriteriakriteria yang digunakan untuk menilai saham yang dijadikan dasar bagi investor dalam melakukan keputusan investasi menggunkaan model dari penelitian (Yohantin, 2009) adalah Beta saham lebih dari 1, artinya saham terebut 
tergolong saham yang agresif, menghasilkan excess return positif $(+) /$ undervalue $[\mathrm{E}(\mathrm{Ri})>$ $\mathrm{E}(\mathrm{Rj})]$, terdapat hubungan yang linier antara risiko dan return saham, dan menghasilkan beta $(\beta)$ yang signifikan. Hasil kriteria-kriteria penilaian saham disajikan pada tabel 2 .

Tabel 2. Klasifikasi Saham Sebagai Keputusan Investasi

ADRO, ASII, BSDE, INDF, KLBF, SMGR, dan WIKA. Artinya ke tujuh saham tersebut termasuk kedalam saham yang agresif. Hasil ini menunjukan bahwa tujuh saham tersebut memiliki kepekaan yang lebih besar dari fluktuasi yang terjadi di pasar, sehingga return dan risiko saham tersebut lebih besar

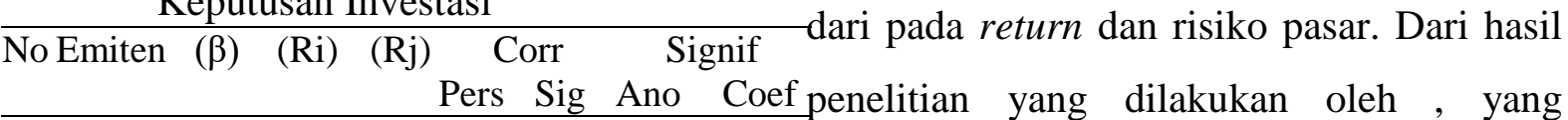
1 ADRO 1,1860,0020,0020,3990,0010,000 0,001

2 AKRA 0,0230,0020,0040,3430,0030,000 0,003 melakukan penelitian tentang penilaian return 3 ASII 1,2450,0020,0020,7040,0000,000 0,000 dan risiko dengan menggunakan CAPM pada 4 BSDE 1,3570,0020,0020,6240,0000,000 0,000

5 ICBP 0,6220,0040,0040,2700,0220,000 0,022 JII periode 2014-2016, bahwa terdapat 12 6 INDF $1,0720,0030,0030,5690,0000,0000,000$

7 KLBF 1,1150,0030,0030,6650,0000,000 0,000 saham yang termasuk saham yang agresif, 8 SMGR 1,2300,0020,0020,5060,0000,000 0,000 dimana dari 12 saham tersebut terdapat 6 9 TLKM 0,7800,0040,0040,5060,0000,000 0,000 10 UNTR 0,5080,0050,0050,2480,0360,000 0,036 saham yang sama dengan hasil penelitian ini, Berdasarkan data klasifikasi Saham Sebagai Keputusan Investasi maka saham saham yang layak berdasarkan kriteriakriteria penilaian investasi tersebut dapat terlihat pada tabel 3 .

Tabel 3. Klasifikasi Saham Sebagai Keputusan Investasi Lanjutan

No Emiten Interpretasi yaitu ADRO, ASII, BSDE, INDF, KLBF, dan WIKA termasuk saham yang agresif.

Sedangkan sisanya 5 dari 12 sampel memiliki nilai $\beta<1$, yaitu saham AKRA, ICBP, TLKM, UNVR, dan UNVR. Artinya ke lima saham tersebut termasuk kedalam saham yang devensive. Hasil ini mẹpunjukkan bahwa lima saham tersebut ( $\beta) \quad(\mathrm{Rj}) \quad$ Corr Ano Coef memiliki kepekaan yang lebih kecil dari 1 ADRO Agresif undervalue Nyata linear $\beta$ signf Layak

2 AKRA defensif overvalue Nyata linear $\beta$ signf flulk dkasi yang terjadi di pasar, sehingga

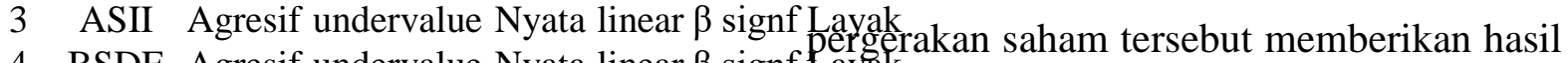
4 BSDE Agresif undervalue Nyata linear $\beta$ signf Layak

5 ICBP defensif undervalue Nyata linear $\beta$ signf keryalia dan risiko yang lebih kecil 6 INDF Agresif undervalue Nyata linear $\beta$ signf Layak

7 KLBF Agresif undervalue Nyata linear $\beta$ signf dibandingkan dengan return dan risiko pasar.

8 SMGR Agresif overvalue Nyata linear $\beta$ signf Layakkan tetapi, jika dilihat dari tingkat 9 TLKM defensif undervalue Nyata linear $\beta$ signf Layak

10 UNTR defensif overvalue Nyata linear $\beta$ signf signilfikansi semua beta signifikan.

Berdasarkan tabel diatas, bahwa terdapat 7 saham dari 12 saham yang dijadikan sampel menghasilkan beta lebih dari 1, yaitu saham
Selanjutnya, berdasarkan excess return terdapat 3 saham dari 12 saham memiliki nilai excess return yang negatif (overvalue), 


\section{Nominal: Barometer Riset Akuntansi dan Manajemen}

P-ISSN: 2303-2065 E-ISSN: 2502-5430

Volume 10 No 1 (2021)

artinya nilai expected return dari ke 3 saham tersebut lebih kecil dari required return. Saham - saham tersebut adalah AKRA, SMGR, dan UNTR. Jika saham yang overvalue maka keputusannya yaitu dijual. Sedangkan sisanya 9 saham menghasilkan nilai excess return yang positif (undervalue), artinya expected return dari 9 saham tersebut lebih besar dari required return. Sahamsaham tersebut adalah ADRO, ASII, BSDE, ICBP，INDF，KLBF，TLKM，UNVR， dan WIKA. Jika saham yang undervalue maka keputusannya yaitu dibeli. Dari hasil penelitian yang dilakukan oleh (HARDIYANTI, Prijanto and Amsori, 2020), yang melakukan penelitian tentang penilaian return dan risiko dengan menggunakan CAPM pada JII periode 2014 -2016, dimana terdapat 12 saham yang undervalue, dimana dari 12 saham tersebut ada 8 saham yang sama dengan hasil penelitian ini, yaitu saham ADRO, ASII, BSDE, INDF, KLBF, TLKM, UNVR, dan WIKA termasuk kedalam saham yang undervalue.

Kemudian, dilihat dari tabel 3 diatas, terlihat bahwa nilai signifikansi kedua belas saham tersebut $<0,05$. Artinya ada hubungan antara risiko dan return saham ke sembilan belas saham tersebut. Dimana, kedua belas saham tersebut memiliki hubungan positif antara risiko dan return. Artinya jika return naik maka risiko juga akan ikut naik, dan sebaliknya. Hasil penelitian ini sesuai dengan hasil penelitian (Anton and Ervita Safitri, 2014), dan (Yohantin, 2009), dimana terdapat hubungan positif antara risiko dan return.

Kriteria-kriteria yang digunakan untuk menilai saham dengan menggunakan model penelitian (Yohantin, 2009), sehingga diperoleh enam saham yang tidak layak untuk diinvestasikan, yaitu saham AKRA, ICBP, SMGR, TLKM, UNTR, dan UNVR. Sedangkan saham yang layak untuk diinvestasikan sebanyak enam saham, yaitu saham ADRO, ASII, BSDE, INDF, KLBF, dan WIKA. Karena menghasilkan beta $(\beta)>$ 1 (agresif) dan signifikan, excess return positif (undervalue), serta return dan risiko memiliki hubungan yang linier.

Penelitian yang dilakukan (Yohantin, 2009) yang menganalisis saham dengan menggunakan CAPM periode 2004 - 2008 di Jakarta Islamic Indeks (JII). Hasil penelitiannya menyimpulkan terdapat 9 saham yang layak untuk diinvestasikan . Dari kesembilan saham tersebut ada 1 (satu) saham yang sama dengan hasil penelitian ini yaitu saham KLBF (Kalbe Farma Tbk).

Kemudian penelitian yang dilakukan oleh (Anton and Ervita Safitri, 2014), yang menganalisis hubungan return dan risiko saham dengan menggunakan CAPM Pada JII periode 2009 - 2012. Hasil penelitiannya menyimpulkan terdapat 4 saham yang layak untuk diinvestasikan. Dari kesembilan saham tersebut ada 1(satu) saham yang sama dengan 
hasil penelitian ini yaitu saham KLBF (Kalbe Farma Tbk). Artinya saham KLBF dari periode 2004 - 2012 dan 2014 - 2019 masih menjadi saham yang layak untuk diinvestasikan.

\section{Uji Asumsi Klasik}

\section{Uji Heteroskedastisitas}

Dalam penelitian ini, uji heteroskedastisitas menggunakan Uji White. Hasil uji heteroskedastisitas disajikan pada tabel 4 ..

Tabel 4. Hasil Uji Heteroskedastisitas

\begin{tabular}{|c|c|c|c|}
\hline \multicolumn{4}{|c|}{ Heteroskedastisitas } \\
\hline F-statistic & 1.617181 & $\begin{array}{l}\text { Prob. F } \\
(2.3)\end{array}$ & 0.3338 \\
\hline $\begin{array}{l}\text { Obs*R- } \\
\text { Squared }\end{array}$ & 3.112776 & $\begin{array}{l}\text { Prob. Chi } \\
\text { Square (2) }\end{array}$ & 0.2109 \\
\hline $\begin{array}{l}\text { Scaled } \\
\text { explained } \\
\text { SS }\end{array}$ & 0.760242 & $\begin{array}{l}\text { Prob. Chi } \\
\text { Square (2) }\end{array}$ & 0.6838 \\
\hline
\end{tabular}

Berdasarkan tabel 4 diatas bahwa nilai $p$ value obs ${ }^{*} R$-square sebesar 0,2109. Maka dapat disimpulkan bahwa penelitian ini bebas dari heteroskedatisitas karena $p$ value obs $* R$ square $0,2109>\alpha 0,05$.

\section{Uji Autokorelasi}

Uji autokorelasi penelitian ini mengunakan uji Dorbin Watson (DW). Penelitian ini terbebas dari autokorelasi karena menghasilkan nilai Dorbin Watson stat sebesar 1,629844. Dimana nilai tersebut lebih besar dari dL 1,55 dan lebih kecil dari Du 2,46 .

\section{Uji Normalitas Residual}

Penelitian ini menggunakan metode Jarque - Bera dalam uji normalitas residual. Hasil uji normalitas disajikan pada gambar 2

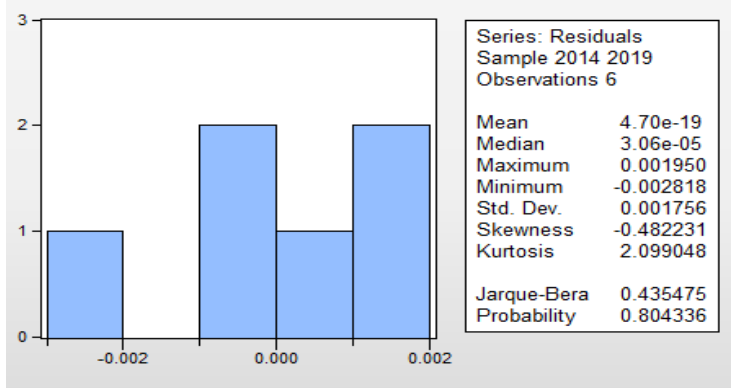

Gambar 2. Hasil Uji Normalitas Residual

Berdasarkan gambar diatas nilai Probability sebesar $0,804336>\alpha 0,05$. Artinya residual berdistribusi normal.

\section{Uji Stasioneritas Data}

Pengujian stasioneritas data dilakukan agar terhindar dari salah satu dari dua kondisi yaitu terjadinya kointegrasi atau terjadinya regresi rancung (Spurious regression atau regresi semu). Untuk menguji stasioneritas data, penelitian ini menggunakan cara uji akar unit (uji unit root) atau sering disebut dengan uji formal. Hasil uji stasioneritas disajkikanpad tabel 5.

Tabel 5. Hasil Uji Stasioneritas Data

\begin{tabular}{lll}
\hline Method & Statistic & Prob.** \\
\hline ADF - Fisher Chi-square & 282.438 & 0.0000 \\
ADF - & -14.7892 & 0.0000 \\
\hline
\end{tabular}

\section{SIMPULAN DAN SARAN}

\section{Simpulan}

Pada periode Januari 2014 sampai Desember 2019 dari 12 saham yang dijadikan sampel hanya 7 saham memiliki nilai $\beta>1$, 
yaitu saham ADRO, ASII, BSDE, INDF, KLBF, SMGR, dan WIKA. Kemudian, 9 saham dari 12 sampel yang menghasilkan nilai excess return yang positif (undervalue), yaitu ADRO, ASII, BSDE, ICBP, INDF, KLBF, TLKM, UNVR, dan WIKA. Selanjutnya nilai signifikansi kedua belas saham tersebut $<0,05$. Artinya ada hubungan antara risiko dan return saham ke sembilan belas saham tersebut. Kriteria-kriteria yang digunakan untuk menilai saham dengan menggunakan model penelitian (Yohantin, 2009), dimana terdapat enam saham yang layak untuk diinvestasikan, yaitu ADRO, ASII, BSDE, INDF, KLBF, dan WIKA.

\section{Saran}

Capital Asset Pricing Model (CAPM) merupakan salah satu model yang dapat digunakan oleh investor untuk memprediksi saham-saham mana saja yang layak untuk diinvestasikan. Sehingga investor dapat menggunakan CAPM dalam penentuan aksi jual dan beli saham berdasarkan saham tersebut masuk kedalam undervalue atau overvalue. Kemudian untuk penelitian selanjutnya, berkaitan dengan periode dapat memperpanjang periode penelitian agar hasilnya lebih representative. Selain itu berkaitan dengan populasi penelitian dapat memperluas populasi sehingga hasilnya dapat lebih digeneralisir untuk pengambilan keputusan investasi di pasar modal

\section{DAFTAR PUSTAKA}

Anton and Ervita Safitri (2014) 'Analisis Hubungan Return dan Risiko Saham dengan Menggunakan Metode Capital Asset Pricing Model CAPM pada Jakarta Islamic Indekx (JII)', Jurnal MDP.

Black, F., Jensen, Michael, C. and Scholes, M. (1972) 'The capital Asset Pricing Model: Some Empirical Tests', in Studies in The Theory of Capital Markets, M. C. Jensen Edi. preanger publishers.

Brav, A., Lehavy, R. and Michaely, R. (2005) 'Using Expectations to Test Asset Pricing Models', Financial Management, 34(3), pp. 31-64.

Haidiati, D., Topowijono and Azizah, D, F. (2016) 'Penerapan Metode CAPM Sebagai Dasar Pengambilan Keputusan Investasi Saham Studi Kasus Pada Perusahaan yang terdaftar di Indeks IDX30 Periode Juli 2012 - Juni 2015', Jurnal Administrasi Bisnis, 37(2).

Hardiyanti, Y., Prijanto, T. and Amsori (2020) 'Penilaian Return Dan Risiko Sistematis Saham Menggunakan Capital Asset Pricing Model (Studi Kasus Saham Yang Terdaftar Pada Jakarta Islamic Index Tahun 2014-2016)', Jurnal AKuntansi Bisnis \& Ekonomi, 8(2). Available at: https://www.infodesign.org.br/infodesig n/article/view/355\%0Ahttp://www.aberg o.org.br/revista/index.php/ae/article/vie w/731\%0Ahttp://www.abergo.org.br/rev ista/index.php/ae/article/view/269\%0Aht tp://www.abergo.org.br/revista/index.ph p/ae/article/view/106.

Hidayati, A. A., Suhadak and Nengah, S. (2014) 'Analisis Capital Asset Pricing Model (CAPM) Terhadap Keputusan Investasi Saham (Studi pada Perusahaanperusahaan Sektor Perbankan di BEI tahun 2009-2011)', Jurnal Administrasi 
Bisnis, 9(1), pp. 1-7.

Komara, E. F., Febrian, E. and Anwar, M. (2019) 'Analisis Three Factor Fama and French Model terhadap Return pada Indeks Saham Syariah Indonesia ( ISSI ) Periode 2011-2014', jurnal inspirasi Bisnis dan Manajemen, 3(2), pp. 105116.

Kurniawan, F, A., Raden, R, H. and Devi, F, Z. (2015) 'Penerapan Metode CAPM untuk Penentapan Kelompok SahamSaham Efisien Studi Kasus Pada Perusahaan Industri Barang Konsumsi yang Terdaftar di Bursa Efek Indonesia Periode 2011-2013', Jurnal Administrasi Bisnis, 24(1).

Lintner, J. (1965) 'The Valuation of Risk Assets and The Selection of Risky Investment in Stock Portofolio and Capital Budgets', The Reviews of Economics and Statistics, 47(1).

Nasuha, R., Dzulkirom, M. and A, Z. Z. (2012) 'Analisis Metode Capital Asset Pricing Model Dalam Upaya'.

Putra, M, D, H. and Yadnya, I, P. (2016) 'Penerapan CAPM sebagai pertimbangan dalam Pengambilan Keputusan Investasi Saham', E-Jurnal Manajemen Unud, $5(12)$.

Putra, R. A. D. and Irmadariani, R. (2014) Analisis Risiko dan Return Saham dengan Menggunakan Metode CAPM untuk Menentukan Pilihan Berinvestasi pada Saham LQ45 di Bursa Efek Indonesia ( Analysis Risk and Return of Stock with Using CAPM Method to Decide Invesment Choice at LQ45 Stock in Indonesia, artikel Ilmiah Mahasiswa. jember.

Ramli, A. (2010) 'Risk dan Return Saham Perusahaan Industri Barang Konsumsi di Bursa Efek Indonesia', Jurnal Aplikasi Manajemen, pp. 1090-1097.
Ross, A, S., Westerfield, R, W. and Jordan, B, D. (2010) Fundamentals of Corporate Finance. Ninth Edit. New York: Mc Graw-Hill.

Saputra, W. D., Suhadak and Azizah, D. F. (2015) 'Penggunaan Metode Capital Asset Pricing Model (Capm) Dalam Menentukan Saham Efisien (Studi pada Saham-Saham Perusahaan yang Terdaftar di Indeks Kompas 100 Periode 2010-2013)', Jurnal Administrasi Bisnis, 25(1), pp. 1-7.

Sekarwati, H. and Margasari, N. (2015) 'Penggunaan Metode Capital Asset Pricing Model Dalam Menentukan Keputusan Berinvestasi Saham ( Studi Pada Saham Indeks Kompas 100 di Bursa Efek Indonesia )', (1), pp. 425-433.

Sharpe, W. F. (1964) 'Capital Asset Prices: A Theory Of Market Equilibrium Under Conditions Of Risk', Source: The Journal of Finance, 19(3), pp. 425-442.

Yohantin, Y. (2009) Penggunaan Metode CAPM Dalam Menilai Risiko dan Return Saham Untk Menentukan Pilihan Berinvestasi Pada Saham Jakarta Islamic Index Periode Januari 2004-Desember 2008 Di Bursa Efek Indonesia. Depok.

Yulianti, R., Topowijono and Azizah, D, F. (2016) 'Penerapan Metode CAPM untuk Menentukan Kelompok Saham-Saham Efisien', Jurnal Administrasi Bisnis, 38(2). 